\title{
MENGURANGI RISIKO UE MSDS YANG DISEBABKAN OLEH AWKWARD POSTURE DI OPERATOR INSTALASI PT XYZ DENGAN MENGGUNAKAN METODE OCRA INDEX
}

\author{
${ }^{1}$ M Nusem Hudiantoko, ${ }^{2}$ Rino Andias Anugraha, ${ }^{3}$ Yusuf Nugroho D.Y \\ ${ }^{1,2,3}$ Program Studi Teknik Industri, Fakultas Rekayasa Industri, Telkom University \\ 1nusem.hudiantoko@gmail.com, ${ }^{2}$ pak.rino@gmail.com, ${ }^{3}$ doyoyekti2010@gmail.com
}

\begin{abstract}
Abstrak-Kesehatan merupakan suatu hal yang sangat penting bagi manusia. Kesehatan yang baik dapat meningkatkan produktivitas pekerja dengan meningkatkan kapasitas fisik mereka, seperti kekuatan dan daya tahan, serta kapasitas mental mereka, seperti fungsi kognitif dan kemampuan penalaran. Seperti di logistic Division, diketahui bahwa $16 \%$ dari total penyakit yang dialami pegawainya disebabkan oleh saraf dan otot. Dengan menelusuri berdasarkan setiap deprtemen yang ada di divisi ini, pegawai yang paling banyak sakit adalah pada Installation Department yang memberikan kontribusi $60 \%$, itu berarti bahwa dari $16 \%$ penyakit yang disebabkan oleh saraf dan otot $60 \%$ operator yang terinfeksi bekerja dalam Installation Department. Pekerjaan dalam Departemen Instalasi terdapat ada lima line yang memiliki tanggung jawab untuk menginstal mobil tersedia atau diberikan. Dari lima line, yang paling banyak pegawainya sakit adalah pada line 2 yang berkontribusi $25 \%$. Setelah itu, di identifikasi dan hasilnya jenis pekerjaan yang pekerjanya paling banyak sakit adalah pada Pos 2D yang bertanggung jawab untuk menginstal wooden LH dan routing. Setelah itu, kondisi exisitng di nilai dengan menggunakan metode OCRA Indeks yang mengevaluasi empat faktor risiko utama secara kolektif berdasarkan durasi kerja, repetitiveness, kekuatan, postur canggung dan gerakan, dan kurangnya periode pemulihan yang tepat. Kemudian, dari hasil yang diperoleh dari penilaian akan digunakan sebagai parameter untuk memberikan perbaikan yang dalam hal metode perbaikan kerja. Dengan meningkatkan dan mengatur waktu kerja, gap yang telah di kategorikan dalam OCRA Indeks telah diperbaiki. Dengan kata lain Indeks ocra pada kondisi perbaikan lebih rendah dari yang sudah ada. Artinya, proses perbaikan berhasil menurunkan risiko penyakit dari 2,449 ke 1,836 dengan proses perbaikan yang berfokus terhadap empat faktor tersebut.
\end{abstract}

Kata kunci: OCRA Indeks, wooden LH kayu, saraf dan otot, routing, repetitiveness, postur canggung

\section{PENDAHULUAN}

Kesehatan adalah keadaan fisik, mental, maupun kesejahteraan sosial, dan juga tidak adanya penyakit atau kelemahan (WHO, 1946). Kesehatan yang baik dapat meningkatkan produktivitas pekerja dengan meningkatkan kapasitas fisik mereka, seperti kekuatan dan daya tahan, serta kapasitas mental mereka, seperti fungsi kognitif dan kemampuan penalaran. (Savedoff dan Schultz 2000; Schultz 1999a, 1999b, 2002; Schultz dan Tansel 1992; Strauss dan Thomas 1998). Dimana seorang pegawai yang terserang penyakit harus menghabiskan waktu mereka untuk memeriksa atau memulihkan kondisi mereka yang seharusnya mereka pergunakan untuk melakukan pekerjaan mereka dan hal tersebut termasuk sebagai kondisi tidak produktif.

Seperti halnya pada PT. XYZ, dalam menghadapi era penjualan 800.000 pada tahun 2020 Vehicle Logistics Division sebagai bagian dari supply chain harus mempersiapkan semua sumber daya untuk mengakomodasi situasi ini. Berdasarkan data kunjungan poliklinik (Jan-Mei 2014), beberapa penyakit secara signifikan telah berdampak pada efisiensi sumber daya. Berdasarkan data yang sama, yaitu data kunjungan poliklinik dari Januari sampai Mei 2014, beberapa penyakit telah tercatat. Data tersebut menunjukkan bahwa penyakit yang paling banyak diderita berturut-turut adalah saraf dan otot, penyakit pernapasan, dan gastritis. Karena penyakit yang umum tertinggi adalah saraf dan otot, serta sistem pernapasan, dan gastritis adalah penyakit yang disebabkan oleh virus atau bakteri atau dikategorikan sebagai faktor eksternal, maka penyakit yang disebabkan oleh saraf dan otot merupakan fokus dalam penelitian ini.

Dari data yang ada, menunjukkan bahwa $16 \%$ dari total penyakit yang dialami pegawainya disebabkan oleh saraf dan otot. Dengan menelusuri berdasarkan setiap deprtemen yang ada di divisi ini, pegawai yang paling banyak sakit adalah pada Installation Department yang memberikan kontribusi $60 \%$, itu berarti bahwa dari $16 \%$ penyakit yang disebabkan oleh saraf dan otot $60 \%$ operator yang terinfeksi bekerja dalam Installation Department. Pekerjaan dalam Departemen Instalasi terdapat ada lima line yang memiliki tanggung jawab untuk menginstal mobil tersedia atau diberikan. Dari lima line, yang paling banyak pegawainya sakit adalah pada line 2 yang berkontribusi $25 \%$. Setelah itu, diidentifikasi lagi dan hasilnya jenis pekerjaan yang pekerjanya paling banyak sakit adalah pada Pos 2D yang bertanggung jawab untuk menginstal wooden LH dan routing. 


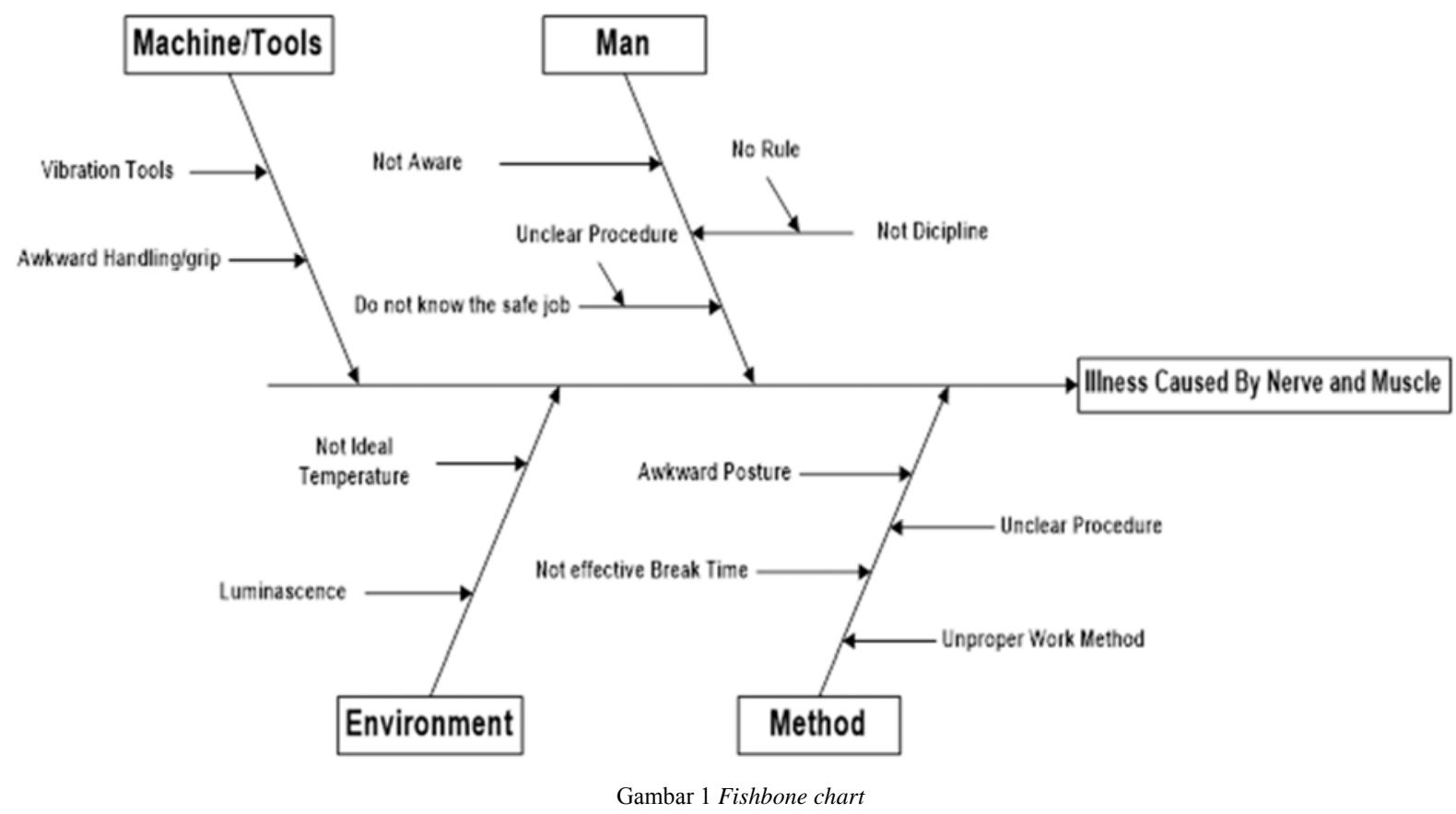

Penjelasana diatas menunjukkan bahwa masih ada $16 \%$ tingkat penyakit yang disebabkan oleh saraf dan otot dan dari penyebab analisis dengan menggunakan fishbone chart yang ditunjukkan pada Gambar 1, itu berarti bahwa analisis ergonomi perlu dilakukan. Oleh karena itu, tujuan dari penelitian ini adalah mengurangi tingkat penyakit yang disebabkan oleh otot dan saraf karena metode kerja yang tidak tepat di Installation Department, Vehicle Logistics Division, PT. XYZ.

\section{METODE PENELITIAN}

Variabel data yang digunakan dalam penelitian ini adalah data kunjungan poliklinik, data postur operator saat bekerja, dan data detail pekerjaan operator. Penyelesaian masalah dalam penelitian ini menggunakan metode OCRA Index sebagai berikut:

1. Tahap Problem Identification dan Preliminary

a. Identifikasi dan klasifikasi masalah

Menjelaskan mengenai proses identifikasi masalah secara rinci, dimana masalah tersebut akan diklasifikasikan dan ditemukan akar masalah atau masalah utama yang perlu diselesaikan. Dalam jurnal ini, tema masalah adalah tentang ergonomi.

b. Studi Lapangan

Studi lapangan ini merupakan studi secara langsung yang dilakukan oleh peneliti guna mengkonfirmasi dan meneliti lebih dalam mengenai permasalahan yang sudah teridentifikasi sebelumnya.

c. Studi Literature

Menemukan dan mencari metode yang tepat sesuai dengan objek penelitian merupakan fokus utama pada tahap ini. Selain itu, proses benchmarking dengan masalah yang serupa juga dilakukan disini. d. Tujuan penelitian

Penentuan tujuan untuk pemecahan masalah dari tahap sebelumnya akan dilakukan dalam tahap ini. Hasil penetapan tujuan ini, nantinya akan dijadikan sebagai parameter keberhasilan dari penelitian yang dijalankan.

e. Penyusunan Konseptual model

Model konseptual adalah kerangka berfikir peneliti untuk menyelesaiakan masalah yang ada. Dimana model yang diberikan harus jelas, terukur dan berurutan.

2. Tahap Pengumpulan dan Analisis Data

a. Pengumpulan Data

Terdapat enam faktor yang akan dicari dan diukur dari objek penelitian yang ditentukan, berikut merupakan keenam faktor tersebut:

a. Action Frequency Constant (CF)

CF merupakan konstanta yang sudah ditetapkan. Pertimbangan praktis dari penerapan implementasi ini di tempat kerja, konstanta frekuensi tindakan (CF) adalah tetap pada 30 tindakan per menit.

b. Force Factor (Ff)

Force adalah representasi langsung baik dari komitmen biomekanik yang diperlukan untuk melaksanakan tindakan teknis yang diberikan. Sulit untuk mengukur kekuatan dalam lingkungan kerja nyata. Untuk mengatasi kesulitan ini, bisa menggunakan skala Borg10kategori peringkat tenaga dirasakan (Borg, 1982). Setelah tindakan yang membutuhkan tenaga telah ditentukan, operator akan diminta 
untuk menganggap masing-masing (atau kelompok homogen) dari mereka skor progresif dari 1 sampai 10.

c. Postural Factor (Fp)

Deskripsi / penilaian terhadap postur harus dilakukan selama siklus perwakilan untuk masing-masing dari therepetitive tugas diperiksa. Ini harus menjadi melalui deskripsi durasi postur dan / atau gerakan dari empat segmen utama anatomi (baik kanan dan kiri): bahu, siku, pergelangan tangan, dan tangan.

d. "Additional” Factor (Fc)

Faktor-faktor ini didefinisikan sebagai tambahan bukan karena mereka penting detikary, tetapi karena masing-masing dari mereka dapat hadir atau tidak dalam konteks diperiksa. Daftar faktor-faktor ini tidak lengkap dan mencakup penggunaan alat getar; persyaratan untuk akurasi mutlak; kompresi lokal; paparan pendingin dingin atau; penggunaan sarung tangan yang mengganggu kemampuan penanganan yang diperlukan; benda ditangani memiliki permukaan licin; gerakan tiba-tiba, "merobek" atau "merobek" gerakan, atau gerakan cepat; dampak berulang (misalnya, palu, memukul, dll).

e. "Recovery Periods" Factor (Fr)

Sebuah periode pemulihan adalah periode di mana satu atau lebih kelompok otot-tendon pada dasarnya saat istirahat yang istirahat, tugas pengendalian visual, dan periode dalam siklus yang meninggalkan kelompok otot benar-benar beristirahat berturut-turut selama setidaknya 10 detik hampir setiap beberapa menit.

f. Duration Factor (Fd)

Dalam pergeseran bekerja, durasi keseluruhan tugas dengan gerakan atas-anggota badan berulang dan menentukan eksposur secara keseluruhan. Waktu rekomendasi untuk pekerjaan ini dalam sehari adalah 6 sampai 8 jam.

g. Perhitungan hasil OCRA Index

Perhitungan dilakukan dengan memberikan parameter yang diperlukan untuk menangani semua faktor multiplier dan menghitung indeks ocra dengan rumus. Hasil ini memberikan dasar untuk menunjukkan tindakan yang dianjurkan teknis sesuai dengan indeks ocra.

h. Klasifikasi hasil OCRA Index

Dengan mempertimbangkan hasil indeks ocra, langkah berikutnya adalah ocra kriteria klasifikasi indeks dan menunjukkan tindakan pencegahan konsekuen untuk diadopsi oleh informasi yang diberikan.
3. Tahap Perbaikan

a. Analisis OCRA Index

Pada tahap ini, dimulai dengan menganalisis nilai OCRA Index yang sudah didapat dari perhitungan sebelumnya. Dimulai dengan analisis klasifikasi tingkat bahaya, kemudian klasifikasi setiap faktor yang ada, setelah itu memilah faktor manakah yang perlu dilakukan perbaikan.

b. Proses Perbaikan

Setelah dilihat dari setiap faktor tersebut terdapat beberapa faktor yang perlu diperbaiki, dan ditahap perbaikan ini, fokus utamanya adalah dengan mengatur dan memperbaiki postural factor.

4. Tahap Evaluasi

Dari tahap perbaikan yang dilakukan, kemudian akan dilakukan estimasi nilai OCRA Index untuk kondisi usulan, dimana hasilnya akan dibandingkan dengan nilai OCRA Index kondisi awal.

\section{DISKUSI}

\section{Pengumpulan Data}

Data yang diperlukan dalam penelitian ini adalah data kegiatan operator saat bekerja yang akan dibagi sampai technical acions untuk tangan kanan dan kiri. Selain itu, data posisi operator, data waktu kerja juga dibutuhkan. Berikut merupakan gambar operator saat mengerjakan pekerjaannya yang ditunjukkan dalam Gambar 3.

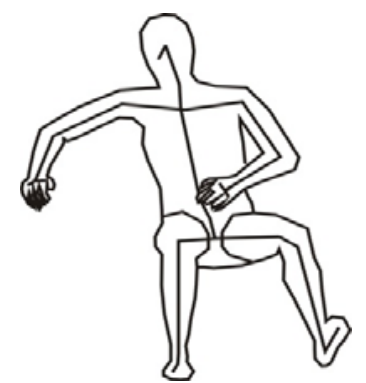

Gambar 2 Postur operator saat bekerja

Gambar 2 menunjukan postur operator saat bekerja, dimana postur tersebut akan dinilai untuk dijadikan salah satu faktor penilaian dalam OCRA Index.

\section{Pengolahan Data}

Setelah mengumpulkan data, langkah selanjutnya adalah pengolahan data, dimana langkah pertamanya adalah menghitung nilai Actual Technical Action dari operator saat mereka bekerja.

Dalam proses pengumpulan data diperoleh nilaiwaktu siklus adalah 7,43 menit atau 445,8 detik. Untuk perhitungan frekuensinya dapat dilihat dalam proses berikut : 
Frekuensi $=($ Total Technical Action x 60) $/$ Waktu siklus

Frekuensi Tangan Kanan $=(172 \times 60) / 445,8$

$=23,149$ technical action/minutes

Frekuensi Tangan Kiri $=(98 \times 60) / 445,8$

$=13,189$ technical action/minutes

Nilai total technical action dapat dihitung dengan cara mengalikan nilai frekuensi dan total waktu kerja operator.

ATA $=$ Frekuensi $x$ Total Working Time

ATA $_{\text {Tangan Kanan }}=23,149$ x $420=9722,58$ actions

ATA $_{\text {Tangan Kiri }}=13,189 \times 420=5539,70$ actions

Langkah selanjutnya adalah menghitung recommended technical action dimana dalam proses ini, dilakukan perhitungan untuk setiap faktor, yaitu force factor, posture factor, additional risk factor, recovery time factor dan duration determination seperti terlihat pada Tabel I berikut :

TABEL I

\begin{tabular}{|c|c|c|}
\multicolumn{3}{|c|}{ NILAI SETIAP FAKTOR PADA RTA CALCULATION } \\
$\begin{array}{c}\text { OCRA } \\
\text { Faktor }\end{array}$ & Tangan Kanan & Tangan Kiri \\
CF & $\begin{array}{c}30 \text { technical } \\
\text { action/min }\end{array}$ & $\begin{array}{c}30 \text { technical } \\
\text { action } / \text { min }\end{array}$ \\
\hline Ff & 0,848 & 0,904 \\
Fp & 0,5 & 0,7 \\
\hline Fc & 0,9 & 0,95 \\
\hline D & 420 menit & 420 menit \\
\hline Fr & 0,75 & 1 \\
\hline Fd & 1,1 & 1,1 \\
\hline
\end{tabular}

RTA Tangan Kanan $\quad=3970,19$ Technical Action RTA Tangan Kiri $\quad=7692,66$ Technical Action

Dengan membandingkan nilai ATA dan skor RTA, hasil untuk OCRA Indeks dapat diidentifikasi. Kemudian, hasilnya akan dikategorikan sebagai kegiatan yang optimal atau beresiko tinggi. Karena, hasil OCRA Index tangan kanan 2,4489 dan untuk tangan kiri adalah 0,7201. Dengan kata lain, kegiatan tangan kiri dalam kondisi optimal dan kegiatan tanga kanan dikategorikan sebagai daerah kuning/merah atau perlu ditingkatkan dan diperlukan perbaikan.

\section{Analisis}

Setelah mengetahui nilai OCRA Index untuk tangan kiri dan tangan kanan, dapat kita simpulkan bahwa masih harus ada perbaikan untuk tangan kanan seperti yang ditunjukkan dalam Tabel II berikut :
TABEL II

GAP DARI NILAI SCORE TANGAN KANAN DAN KIRI

\begin{tabular}{|c|c|c|c|}
\cline { 2 - 4 } \multicolumn{1}{c|}{} & $\begin{array}{c}\text { OCRA } \\
\text { Index }\end{array}$ & $\begin{array}{c}\text { Skor } \\
\text { Optimum }\end{array}$ & Gap \\
\hline Tangan Kanan & 2,449 & 1,5 & 0,949 \\
\hline Tangan Kiri & 0,72 & 1,5 & - \\
\hline
\end{tabular}

Gap pada OCRA skor tangan kanan menunjukkan bahwa aktivitas pada tangan kanan sangat risiko gangguan muscoloskeletal dan dapat berakibat pada tingkat penyakit secara tidak langsung. Oleh karena itu, kondisi perbaikan yang dapat dilakukan dengan peningkatan dan memperbaiki setiap kondisi faktor indeks ocra harus dilakukan.

Karena skor akhir untuk tangan kanan faktor postural adalah 0,5 sehingga masih memiliki kemungkinan yang tinggi untuk memperbaiki kondisi faktor postural. Dari detail informasi skor postural assesment, skor terendah postural yang berasal dari posisi bahu $48^{\circ}$ (abduction $45^{\circ}$ $-80^{\circ}$ ) yang memiliki waktu proporsi $81,2 \%$ dari waktu siklus. Tidak hanya itu grip jenis tangan palmar segmen postural juga memiliki skor rendah. Nilai postural dari pegangan tangan (palmar grip) adalah 0,7 yang memiliki waktu proporsi $44 \%$ dari total waktu siklus.

\section{Proses Perbaikan}

Risiko nilai postural di OCRA Indeks disebabkan oleh posisi bahu (abduction $45^{\circ}-80^{\circ}$ ) yang memiliki $81,2 \%$ proporsi waktu dari yang waktu siklus dan posisi pegangan tangan (palmar grip) yang memiliki waktu proporsi $44 \%$ dari total waktu siklus. Setelah masalah dalam faktor postural teridentifikasi, langkah berikutnya adalah menentukan akar penyebabnya. Dari akar penyebab yang telah diketahui, countermeassure untuk setiap masalah dapat ditentukan. Diperoleh bahwa postur baru operator adalah salah satu penyelesaiannya. Alternatif postur yang dikembangkan yang ditunjukkan dalam Tabel 3 .

Setelah meneliti lebih lanjut posisi untuk setiap alternatif, didapat kesimpulan bahwa alternatif terpilih adalah sitting sideways position hal tersebut dikarenkan posisi ini masalah mengenai posisi bahu abduction dapat terselesaikan, namun di posisi alternatif lain, seperti pada posisi berdiri malah menimbulkan masalah lain, yakni awkward legs position dan pada posisi get into the car menimbulkan masalah bending dan twisting.

Namun, di sisi lain postur baru ini tidak mencakup masalah genggaman tangan (palmar grip). Jadi, masalah mengenai palmar handgrip, yang memiliki 0,7 skor menjadi segmen paling bermasalah dalam perhitungan nilai postural faktor. Dengan kata lain, nilai postural baru yang ditunjukkan pada Tabel III adalah 0,7 yang dihitung dari palmar grip. 
TABEL III

POSTUR ALTERNATIF

Posisi Berdiri

1. Analisis

Untuk mengetahui apakah saran yang diberikan lebih baik dari kondisi eksisting maka proses perbandingan hasil dari kedua kondisi tersebut akan dilakukan. Tes ini dilakukan dengan menghitung ulang OCRA Indeks berdasarkan faktor-faktor yang telah diperbaiki. Hasil perbandingan selesai jika skor OCRA Indeks pada kondisi usulan lebih kecil atau lebih aman dari nilai yang kondisi eksisting.

Dikarenakan terjadi perbaikan faktor postural posisi abduction dapat diperbaiki sementara masalah pada palmar grip masih ada, sehingga faktor terkecil yang mengacu pada faktor postural adalah 0,7 yang berasal dari tindakan palmar grip.

Dan juga terdapat perbaikan dalam faktor force, faktor additional risk, faktor recovery time namun tidak dijelaskan dalam jurnal ini. Kemudian didapat nilai tiap faktor yang baru seperti terlihat pada Tabel IV.
TABEL IV

NILAI SETIAP FAKTOR PADA RTA CALCULATION USULAN

\begin{tabular}{|c|c|}
\hline $\begin{array}{c}\text { OCRA } \\
\text { Faktor }\end{array}$ & Tangan Kanan \\
\hline CF & $\begin{array}{c}30 \text { technical } \\
\text { action } / \text { min }\end{array}$ \\
\hline Ff & 1 \\
\hline Fp & 0,7 \\
\hline Fc & 0,95 \\
\hline $\mathrm{D}$ & 420 menit \\
\hline Fr & 1 \\
\hline Fd & 1,1 \\
\hline
\end{tabular}

RTA right hand $=9216,9$ Technical Action

Dari hasil perhitungan RTA, maka langkah selanjutnya adalah menghitung OCRA Indeks yang membandingkan ATA dari kondisi yang ada dan meningkatkan nilai RTA. Kemudian, hasilnya adalah 1.054 setelah dilakukan perhitungan. Dengan kata lain, kondisi membaik dalam kegiatan tangab kanan, karena nilai OCRA Index $\leq 1,5$ dan dikategorikan sebagai kondisi optimum.

\section{KESIMPULAN}

Dari seluruh proses penelitian ini, kesimpulan yang dapat negara adalah pertama, kondisi yang ada di operator tersebut yang bekerja di departemen instalasi tidak dalam kondisi optimal. Kondisi yang ada memiliki tingkat penyakit yang tinggi di daerah tersebut, juga dengan skor OCRA Indeks yang menyatakan kegiatan tangan kanan operator di daerah kuning atau dibutuhkan adanya perbaikan.

Kedua, dari kondisi yang ada, proses perbaikan dilakukan dalam meningkatkan kondisi setiap faktor. Untuk faktor postural dapat dilakukan perbaikan, posisi abduction bisa diperbaiki sementara palmar grip masih ada dengan memberikan postur alternatif baru yang posisi sideway seperti pada Gambar 3, sehingga faktor terkecil yang mengacu pada faktor postural adalah 0,7 yang berasal dari tindakan palmaris pegangan.

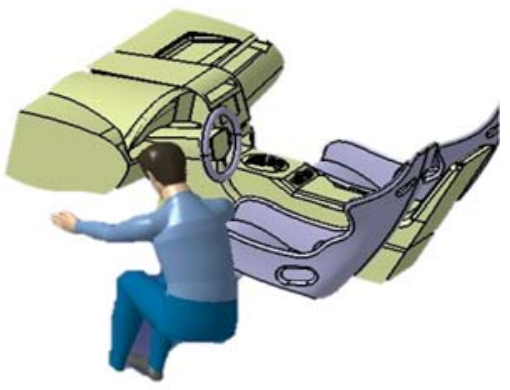

Gambar 3 Postur Usulan

Kemudian dilakukan juga perbaikan dengan faktor force, additional risk dan recovery time. Kesimpulan ketiga, hasil perbaikan dan peningkatan sistem yang diterjemahkan ke ditetapkan dalam pedoman buku terbukti mengatasi gap dari kondisinya keluar 
dibandingkan dengan kondisi ideal. Ini dibuktikan dengan hasil OCRA indeks skor menurun dari 2,4489 ke 1.054.

\section{DAFTAR PUSTAKA}

[1] Ayoub, M., "The Psychologhycal Approarch to Material Handling Task Design. Journal of Ergonomic", 7. 1999.

[2] Chiasson, Marie-Eve., "Comparing The Results of Eight Methods Used to Evaluate Risk Factors Associated with Musculoskeletal Disorders". Department of Mathematics and Industrial Engineering, École Polytechnique de Montréal, Canada, 2012.

[3] Kroemer, K.H.E., Kroemer, H.B., Kroemer-Elbert, K.E, "Ergonomics: How to Design for Ease and Efficiency", 2nd Edition, Penerbit Prentice Hall, Inc., Upper Saddle River, New Jersey. USA, 2001.

[4] Kumar, Pradip., "Design and Implementation of Ergonomic Performance Measurement System at Tata Steel Plant in India". Department of Industrial Engineering and Management, Indian Institute of Technology Kharagpur, Kharagpur, 2012.
[5] Molenc, V., "Behavioural Change Phases of Diffrent Stakeholder Involved in The Implementation Process". 448-449. 2007.

[6] Mufti, D., “Kajian Postur Kerja Pada Pengrajin Tenun Songket pada Siket". 11. 2013.

[7] Nurmianto, E. "Ergonomi Konsep Dasar dan Aplikasinya" . Surabaya: Guna Widya. 2008.

[8] Sarmauly, S.’Evaluasi Postur Tubuh di Tinjau Dari Segi Ergonomi di Bagian Pengepakan PT Coca Cola Booting Indonesia Medan”. Skripsi Teknik Industri USU Medan. 2009.

[9] Sihombing,Umberto., "Pengaruh Keterlibatan Dalam Pengambilan Keputusan,Penilaian pada Lingkungan Kerja dan Motivasi Berprestasi Terhadap Kepuasan Kerja Pamong Praja”. Jakarta, 2004.

[10] Wignjosoebroto, Sritomo, et al., "Perancangan Lingkungan Kerja dan Alat Bantu yang Ergonomis untuk Mengurangi Masalah Back Injury dan Tingkat Kecelakaan Kerja pada Departemen Mesin Bubut'. Jurnal Institut Teknologi Sepuluh Nopember (ITS). Surabaya. 